\title{
ANALISIS FAKTOR TINGKAT PENGETAHUAN MASYARAKAT TENTANG TINDAKAN SWAMEDIKASI DIARE
}

\section{ANALYSIS OF COMMUNITY KNOWLEDGE FACTORS ABOUT DIARGE SWAMEDICATION MEASURES}

\author{
Kiki Ambar Kurniasih ${ }^{1^{*}}$, Supriani ${ }^{2}$, Definingsih Yuliastuti ${ }^{3}$ \\ ${ }^{1,2,3}$ Program Studi S1 Farmasi Stikes Paguwarmas Maos Cilacap \\ Email : ${ }^{1}$ Kikiambar50@gmail.com
}

\begin{abstract}
ABSTRAK
Masyarakat melakukan swamedikasi untuk mengatasi keluhan-keluhan dan penyakit ringan seperti diare. Data kasus diare di fasilitas kesehatan Provinsi Jawa Tengah sejumlah 924.926 dan jumlah yang baru tertangani $45,1 \%$. Tujuan penelitian ini untuk mendapatkan gambaran tingkat pengetahuan masyarakat Jangrana Kecamatan Kesugihan Kabupaten Cilacap terhadap tindakan swamedikasi diare. Penelitian ini merupakan penelitian deskriptif dan survei yang bersifat analitik dengan menggunakan metode cross sectional. Pengumpulan data menggunakan teknik wawancara dan angket (kuesioner). Analisis data menggunakan metode analisis variansi tunggal dan uji statistik Chi-Square. Hasil penelitian menunjukkan bahwa mayoritas masyarakat Desa Jangrana memiliki tingkat pengetahuan terhadap tindakan swamedikasi diare dengan kategori baik yang ditunjukkan 221 responden $(69,9 \%)$, cukup 69 responden $(21,8 \%)$, dan kurang $26(8,2 \%)$. Hasil uji Chi-Square menunjukkan bahwa umur, pendidikan, dan pekerjaan memiliki hubungan yang signifikan dengan tingkat pengetahuan terhadap tindakan swamedikasi diare, sedangkan jenis kelamin tidak memiliki hubungan yang signifikan dengan tingkat pengetahuan terhadap tindakan swamedikasi diare.
\end{abstract}

Kata Kunci : Diare, Jangrana, Pengetahuan, Swamedikasi

\begin{abstract}
Swamedication has been done by the community to cope minor diseases such as diarrhea. Diarrhea data in the central province of java about 924.926 a year, and $45,1 \%$ is handled. The purpose in this research is get a description of Jangrana community knowledge about diarrhea swamedication. The descriptive and cross sectional method is use in this research. Data collected with interviews and questionnaires. Univariate and chi square statistical tests is use to analysis data. The result of this research shown that Jangrana community have a knowledge diarrhea in three categories including mild, moderate, and high. The result of chi square tests shown that age, education, and work affect knowledge level swamedication diarrhea.
\end{abstract}

Keywords : Diarrhea, Jangrana, Knowledge, Swamedication

\section{PENDAHULUAN}

Swamedikasi merupakan tindakan mengobati diri sendiri dengan obat yang sederhana dan dibeli bebas di apotek atau toko obat atas inisiatif sendiri tanpa nasihat dari dokter atau tenaga kesehatan. ${ }^{1}$ Faktor yang mempengaruhi tindakan swamedikasi diantaranya mendesaknya perawatan yang dibutuhkan, penanganan pertama pada pasien sakit, ekonomi masyarakat yang rendah, tidak percaya kepada tenaga medis dan pengaruh informasi dari iklan. Faktor yang paling utama pada masyarakat untuk melakukan tindakan swamedikasi yaitu karena terbatasnya akses kesehatan di daerah $^{2}$. Diare merupakan gangguan buang air besar. Hal tersebut ditandai dengan buang air besar lebih dari 3 kali sehari dengan konsistensi tinja yang cair dan dapat disertai dengan darah. ${ }^{3}$ 
Hasil Riset Kesehatan Dasar (RISKESDAS) Tahun 2013 menyatakan bahwa sejumlah 103.860 atau $35,2 \%$ dari 294.959 rumah tangga di Indonesia menyimpan obat untuk swamedikasi. Tingkat penyimpanan obat tertinggi pada rumah tangga berada di Provinsi DKI Jakarta sejumlah $56,4 \%$ dan tingkat penyimpanan obat terendah berada di Provinsi Nusa Tenggara Timur sebesar $17,2 \%$. Rumah tangga di Indonesia rata-rata menyimpan hampir 3 macam obat. Data dari 35,2\% rumah tangga yang menyimpan obat menunjukan penyimpanan obat keras $35,7 \%$ dan antibiotika $\quad 27,8 \%$ Swamedikasi menggunakan obat keras dan obat antibiotika menunjukkan adanya penggunaan obat yang tidak rasional. Data lain menyebutkan bahwa terdapat $81,9 \%$ rumah tangga menyimpan obat keras dan $86,1 \%$ rumah tangga menyimpan antibiotika yang diperoleh tanpa resep dari dokter. $^{3}$

Tahun 2012 angka kesakitan diare pada semua umur sebesar 214 per 1.000 penduduk dan angka kesakitan diare pada balita 900 per 1.000 penduduk. ${ }^{4}$ Data menurut kementerian kesehatan, kasus diare di Provinsi Jawa Tengah pada fasilitas kesehatan sejumlah 924.926 dan jumlah yang tertangani sejumlah $45,1 \%{ }^{5}$ Data menurut Puskesmas Kesugihan II pada Tahun 2018 masyarakat desa Jangrana yang terkena penyakit diare yang berobat hanya 8 orang. Data tersebut menarik peneliti untuk melakukan penelitian tingkat pengetahuan masyarakat Desa Jangrana Kecamatan Kesugihan Kabupaten Cilacap terhadap tindakan swamedikasi diare. Penelitian ini bertujuan untuk mendapatkan gambaran tingkat pengetahuan masyarakat Desa Jangrana Kecamatan Kesugihan Kabupaten Cilacap terhadap tindakan swamedikasi diare. Manfaat penelitian ini diharapkan dapat digunakan sebagai bahan masukan dalam penyusunan program promosi kesehatan yang berkaitan dengan swamedikasi diare bagi masyarakat.

\section{METODE}

Penelitian ini merupakan penelitian deskriptif dan survei yang bersifat analitik dengan menggunakan metode cross sectional. Subjek dalam penelitian hanya diobservasi sekali saja. ${ }^{6} \quad$ Penelitian dilakukan di Desa Jangrana Kecamatan Kesugihan Kabupaten Cilacap. Penelitian dilaksanakan pada periode bulan Maret sampai bulan Mei 2019. Instrumen untuk pengumpulan data dalam penelitian ini menggunakan kuesioner dan teknik wawancara secara langsung. Sampel yang digunakan dalam penelitian ini sejumlah 316 responden. Data yang telah diperoleh diolah dan dianalisis dengan menggunakan analisis univariat dan analisis bivariat dengan nilai signifikansi 0,05 . Analisis bivariat dilakukan dengan menggunakan uji statistik Chi-Square. Uji ini untuk melihat ada tidaknya hubungan antara tingkat pendidikan, jenis kelamin, umur, dan pekerjaan dengan tingkat pengetahuan masyarakat Desa Jangrana mengenai tindakan swamedikasi diare.

\section{HASIL}

Responden pada penelitian ini dibagi menjadi beberapa kategori, yaitu jenis kelamin, umur, pendidikan dan pekerjaan. Umur responden dapat dikategorikan menjadi 5 , remaja akhir yang berumur 1725 tahun, dewasa awal 26-35 tahun, dewasa akhir 36-45 tahun, lansia awal 4655 tahun dan lansia akhir 56-65 tahun ${ }^{7}$ Pendidikan responden dapat dikategorikan menjadi 3 , pendidikan rendah meliputi SD dan SMP, pendidikan menengah jika jenjang pendidikan responden SMA dan pendidikan tinggi jika responden memiliki jenjang pendidikan Diploma/S1/S2/S3. Pekerjaan pada penelitian ini dikategorikan menjadi 5, ibu rumah tangga, buruh, pegawai swasta, pegawai negeri sipil, dan pedagang. Tingkat pengetahuan dikategorikan baik jika $x=76-100 \%$, kategori cukup $x=56-75 \%$, dan kategori kurang jika $x=<56 \% .8$

\begin{tabular}{crc} 
Tabel & $\begin{array}{l}\text { 1. Tingkat } \\
\text { Responden } \\
\text { Swamedikasi Diare }\end{array}$ & \multicolumn{2}{c}{$\begin{array}{c}\text { Pengetahuan } \\
\text { Tentang }\end{array}$} & Tindakan \\
\hline Tingkat Pengetahuan & $\mathrm{N}$ & $\%$ \\
\hline Baik & 221 & 69,9 \\
\hline Cukup & 69 & 21,8 \\
\hline Kurang & 26 & 8,2 \\
\hline Jumlah & 316 & 100 \\
\hline
\end{tabular}


Berdasarkan Tabel 1 diketahui bahwa mayoritas pengetahuan responden tentang swamedikasi diare berada pada kategori baik yaitu 221 responden (69,9\%). Responden yang memiliki pengetahuan kurang hanya 26 orang $(8,2 \%)$.

Tabel 2. Uji Chi-Square Jenis Kelamin dengan Tingkat Pengetahuan Responden Tentang Tindakan Swamedikasi Diare

\begin{tabular}{|c|c|c|c|c|}
\hline \multirow{3}{*}{$\begin{array}{c}\text { Jenis } \\
\text { Kelamin }\end{array}$} & \multicolumn{3}{|c|}{ Tingkat Pengetahuan } & \multirow{3}{*}{$\begin{array}{c}\rho \\
\text { Value }\end{array}$} \\
\hline & Baik & Cukup & Kurang & \\
\hline & $\mathrm{N}(\%)$ & $\mathrm{N}(\%)$ & $\mathrm{N}(\%)$ & \\
\hline $\begin{array}{l}\text { Perempu- } \\
\text { an }\end{array}$ & $107(71,33)$ & $36(24)$ & $7(4,67)$ & \multirow{2}{*}{0,780} \\
\hline Laki-laki & $114(68,67)$ & $\begin{array}{c}33(19, \\
88)\end{array}$ & $19(11,45)$ & \\
\hline
\end{tabular}

Berdasarkan Tabel 2. menunjukkan bahwa tidak terdapat hubungan yang signifikan antara jenis kelamin dengan pengetahuan tentang tindakan swamedikasi diare. Hal ini ditandai dengan $\rho$ value $>0,05(0,78)$.

Tabel 3. Uji Chi-Square Umur dengan Tingkat Pengetahuan Responden Tentang Tindakan Swamedikasi Diare

\begin{tabular}{|c|c|c|c|c|}
\hline \multirow{3}{*}{ Umur } & \multicolumn{3}{|c|}{ Tingkat Pengetahuan } & \multirow{3}{*}{$\begin{array}{c}\rho \\
\text { Value }\end{array}$} \\
\hline & Baik & Cukup & Kurang & \\
\hline & $\mathrm{N}(\%)$ & $\mathrm{N}(\%)$ & $\mathrm{N}(\%)$ & \\
\hline $\begin{array}{l}\text { Remaja } \\
\text { akhir (17-25 } \\
\text { tahun) }\end{array}$ & $\begin{array}{l}29 \\
(82,86)\end{array}$ & $\begin{array}{l}4 \\
(11,43)\end{array}$ & $\begin{array}{c}2 \\
(5,71)\end{array}$ & \multirow{5}{*}{0,000} \\
\hline $\begin{array}{l}\text { Dewasa } \\
\text { awal (26-35 } \\
\text { tahun) }\end{array}$ & $\begin{array}{l}90 \\
(90,91)\end{array}$ & $\begin{array}{c}8 \\
(8,08)\end{array}$ & $\begin{array}{c}1 \\
(1,01)\end{array}$ & \\
\hline $\begin{array}{l}\text { Dewasa } \\
\text { akhir (36-45 } \\
\text { tahun) }\end{array}$ & $54(75)$ & $\begin{array}{l}15 \\
(20,83)\end{array}$ & $\begin{array}{c}3 \\
(4,17)\end{array}$ & \\
\hline $\begin{array}{l}\text { Lansia awal } \\
\text { (46-55 } \\
\text { tahun) }\end{array}$ & $\begin{array}{l}45 \\
(51,14)\end{array}$ & $\begin{array}{l}33 \\
(37,5)\end{array}$ & $\begin{array}{l}10 \\
(11,36)\end{array}$ & \\
\hline $\begin{array}{l}\text { Lansia akhir } \\
\text { (56-65 } \\
\text { tahun) }\end{array}$ & $\begin{array}{c}3 \\
(13,64)\end{array}$ & $\begin{array}{c}9 \\
(40,91)\end{array}$ & $\begin{array}{l}10 \\
(45,45)\end{array}$ & \\
\hline
\end{tabular}

Hasil berbeda ditunjukkan pada Tabel 3 . bahwa umur memiliki hubungan yang signifikan dengan pengetahuan tindakan swamedikasi diare yang ditandai dengan $\rho$ value $\leq 0,05(0,000)$.
Tabel 4. Uji Chi-Square Pendidikan dengan Tingkat Pengetahuan Responden Tentang Tindakan Swamedikasi Diare

\begin{tabular}{|c|c|c|c|c|}
\hline \multirow{3}{*}{ Pendidikan } & \multicolumn{3}{|c|}{ Tingkat Pengetahuan } & \multirow{3}{*}{$\begin{array}{c}\rho \\
\text { Value }\end{array}$} \\
\hline & Baik & Cukup & Kurang & \\
\hline & $\mathrm{N}(\%)$ & $\mathrm{N}(\%)$ & $\mathrm{N}(\%)$ & \\
\hline SD & $\begin{array}{c}53 \\
(41,73) \\
\end{array}$ & $\begin{array}{c}53 \\
(41,73) \\
\end{array}$ & $\begin{array}{c}21 \\
(16,54) \\
\end{array}$ & \multirow{4}{*}{0,000} \\
\hline SMP & $\begin{array}{c}101 \\
(88,60)\end{array}$ & $\begin{array}{l}10 \\
(8,77)\end{array}$ & $3(2,63)$ & \\
\hline SMA & $\begin{array}{c}60 \\
(89,55)\end{array}$ & $5(7,46)$ & $2(2,99)$ & \\
\hline PT & $7(87,5)$ & $1(12,5)$ & 0 & \\
\hline
\end{tabular}

Berdasarkan Tabel 4. Pendidikan memiliki hubungan yang signifikan dengan pengetahuan tindakan swamedikasi diare dengan $\rho$ value 0,000 .

Tabel 5. Hubungan Pekerjaan dengan Tingkat Pengetahuan Responden Tentang Tindakan Swamedikasi Diare

\begin{tabular}{|c|c|c|c|c|}
\hline \multirow{3}{*}{ Pekerjaan } & \multicolumn{3}{|c|}{ Tingkat Pengetahuan } & \multirow{3}{*}{$\begin{array}{c}\rho \\
\text { Value }\end{array}$} \\
\hline & Baik & Cukup & Kurang & \\
\hline & N (\%) & N (\%) & $\mathrm{N}(\%)$ & \\
\hline $\begin{array}{l}\text { lbu rumah } \\
\text { tangga }\end{array}$ & $\begin{array}{c}66 \\
(70,97) \\
\end{array}$ & $\begin{array}{c}23 \\
(24,73) \\
\end{array}$ & $4(4,33)$ & \multirow{5}{*}{0,023} \\
\hline Pedagang & $\begin{array}{c}26 \\
(72,22) \\
\end{array}$ & $\begin{array}{c}7 \\
(19,44) \\
\end{array}$ & $3(8,33)$ & \\
\hline Buruh & $\begin{array}{c}76 \\
(60,32)\end{array}$ & $\begin{array}{c}33 \\
(26,19)\end{array}$ & $\begin{array}{c}17 \\
(13,49)\end{array}$ & \\
\hline $\begin{array}{l}\text { Pegawai } \\
\text { swasta }\end{array}$ & $\begin{array}{c}47 \\
(87,04)\end{array}$ & $5(9,26)$ & $2(3,70)$ & \\
\hline PNS & $\begin{array}{c}6 \\
(85,71) \\
\end{array}$ & $\begin{array}{c}1 \\
(14,29) \\
\end{array}$ & 0 & \\
\hline
\end{tabular}

Untuk variabel pekerjaan yang dapat dilihat pada Tabel 5 menunjukkan bahwa terdapat hubungan yang signifikan antara pekerjaan responden dengan pengetahuan tindakan swamedikasi diare responden yang ditandai dengan nilai $\rho$ value 0,023 .

\section{PEMBAHASAN}

Pengumpulan data penelitian diwakili 316 responden dari $1.754 \mathrm{KK}$ yang merupakan masyarakat Desa Jangrana Kecamatan Kesugihan Kabupaten Cilacap. Uji validitas dan reliabilitas dilakukan pada kuesioner yang akan digunakan pada penelitian ini. Hasil yang didapat kesioner dengan jumlah 16 item dinyatakan valid karena nila $r$ hitung $>r$ tabel. Kuesioner dinyatakan 
reliabel jika nilai Cronbach's Alpha 0,71 atau lebih ${ }^{9}$. Hasil uji reliabilitas yang telah dilakukan pada penelitian ini didapatkan nilai Cronbach's Alpha 0,858.

Hasil tingkat pengetahuan masyarakat Desa Jangrana Kecamatan Kesugihan Kabupaten Cilacap terhadap tindakan swamedikasi diare, mayoritas responden memiliki tingkat pengetahuan dengan kategori baik 221 responden (69,9\%), kategori cukup 69 responden $(21,8 \%)$, dan kategori kurang 26 responden (8,2\%). Hubungan jenis kelamin dengan tingkat pengetahuan masyarakat dapat dilihat pada Tabel 2. Hasil tersebut menunjukkan bahwa variable jenis kelamin memiliki nilai signifikansi sebesar 0,780 > 0,05 artinya tidak ada hubungan yang signifikan dengan tingkat pengetahuan masyarakat Desa Jangrana Kecamatan Kesugihan Kabupaten Cilacap terhadap tindakan swamedikasi diare.

Penelitian ini sejalan dengan penelitian Hermawati (2012) berjudul "Pengaruh Edukasi Terhadap Tingkat Pengetahuan dan Rasionalitas Penggunaan Obat Swamedikasi Pengunjung di Dua Apotek Kecamatan Cimanggis Depok". Berdasarkan hasil penelitian tersebut bahwa karakteristik masyarakat menurut jenis kelamin tidak ada hubungannya dengan tingkat pengetahuan masyarakat ${ }^{10}$. Penelitian ini menunjukkan adanya hubungan yang signifikan antara umur dan pendidikan ( $\rho$ value $0,000<0,05$ ), dengan tingkat pengetahuan terhadap tindakan swamedikasi diare. Hasil ini sejalan dengan penelitian yang telah dilakukan oleh Robiyanto (2018) dengan judul "Analisis Tingkat Pengetahuan Masyarakat Terhadap Tindakan Swamedikasi Diare Akut di Kecamatan Pontianak Timur". ${ }^{11}$

Hubungan pekerjaan dengan tingkat pengetahuan masyarakat ditunjukkan pada Tabel 5. Hasil tersebut menunjukkan bahwa pekerjaan memiliki signifikansi sebesar $0,023(<0,05)$. Hal tersebut memiliki arti bahwa ada hubungan yang signifikan antara pekerjaan dengan tingkat pengetahuan masyarakat Desa Jangrana Kecamatan Kesugihan Kabupaten Cilacap.
Hasil penelitian ini sejalan dengan penelitian yang telah dilakukan oleh Anis (2017) " tentang Hubungan Faktor Sosio demografi Terhadap Pengetahuan Swamedikasi dan Penggunaan Obat Common Cold di Desa Wukirsari Kecamatan Cangkringan Kabupaten Sleman Yogyakarta". Hasil penelitian tersebut menunjukkan bahwa terdapat hubungan antara tingkat pekerjaan masyarakat dengan tingkat pengetahuan. Lingkungan pekerjaan dapat menjadikan seseorang memperoleh pengalaman dan pengetahuan yang baik secara langsung maupun tidak langsung. Pekerjaan juga berkaitan dengan pendapatan seseorang. Jika pendapatan seseorang tinggi maka orang tersebut memilki perilaku swamedikasi yang baik. Pekerjaan membuat antar individu berinteraksi untuk bertukar informasi lebih luas sehingga Informasi yang didapatkan seseorang semakin banyak. ${ }^{12}$

\section{SIMPULAN}

Tingkat pengetahuan masyarakat Desa Jangrana Kecamatan Kesugihan Kabupaten Cilacap tentang tindakan swamedikasi diare memiliki tingkat pengetahuan yang sudah baik. Hasil penelitian ini menunjukkan adanya hubungan yang signifikan antara umur dan pendidikan, pekerjaan dengan tingkat pengetahuan terhadap tindakan swamedikasi diare.

Penelitian ini perlu dilakukan lebih lanjut di daerah yang kondisinya berbeda dengan Desa Jangrana untuk mempermudah pemetaan distribusi obat. Masyarakat harus berperan aktif dan mencari dari manapun dengan sumber terpercaya tentang swamedikasi diare untuk meningkatkan kesehatan masyarakat.

\section{UCAPAN TERIMA KASIH}

Penulis mengucapkan terima kasih kepada:

1. Allah SWT karena atas izin-Nya penulis diberikan kemudahan 
2. Kedua orang tua dan keluarga atas doadoanya sehingga penulis dapat menyelesaikan jurnal ini

3. Ketua Stikes Paguwarmas Maos Cilacap dan Jajarannya.

\section{DAFTAR PUSTAKA}

1. Tan HT dan Rardja K. Swamedikasi. Jakarta. PT. Elex Media Komputindo. 2010

2. Departemen Kesehatan Republik Indonesia. 2009. Jakarta. Sistem Kesehatan Nasional. P 7-8. 2009

3. Badan litbangkes. Riset Kesehatan Dasar. Jakarta. Departemen Kesehatan Republik Indonesia. P 6-7. 2013

4. Kementrian Kesehatan Republik Indonesia. Jakarta. Profil Kesehatan Indonesia Tahun 2014. P. 147-148. 2015

5. Kementrian Kesehatan Republik Indonesia. Jakarta. Data dan informasi Profil Kesehatan Indonesia Tahun 2017. P 144. 2018

6. Notoatmodjo S.Metodologi Penelitian Kesehatan. Jakarta. PT Rineka Cipta. P 37-40. 2010

7. Santika I. Hubungan Indeks Massa Tubuh (IMT) dan Umur Terhadap Daya Tahan Umum (Kardiovaskuler) Mahasiswa Putra Semester II Kelas A Fakultas Pendidikan Olahraga dan Kesehatan IKIP PGRI Bali Tahun 2014. Jurnal Pendidikan Kesehatan Rekreasi. $1: 44.2015$.

8. Nursalam. Konsep dan Penerapan Metodologi Penelitian IImu Keperawatan. Jakarta. Salemba Medika. 2008

9. Alwi I. Kriteria Empirik Dalam Menentukan Ukuran Sampel Pada Pengujian Hipotesis Statistika dan Analisis Butir. Jurnal Formatif 2 (2) : P 145. 2015

10. Hermawati D. Pengaruh Edukasi Terhadap Tingkat Pengetahuan dan Rasionalitas Penggunaan Obat Swamedikasi Pengunjung di Dua Apotek Kecamatan Cimanggis Depok. Skripsi. Depok. 2012

11.Robiyanto, Rosmimi M, Untari EK. Analisis Pengaruh Tingkat Pengetahuan
Masyarakat Terhadap Tindakan Swamedikasi Diare Akut di Kecamatan Pontianak Timur. Jurnal Pendidikan 16 (1) : P.137-138. 2018

12.Anis F. Hubungan Faktor Sosio demografi Terhadap Pengetahuan Swamedikasi dan Penggunaan Obat Common Cold di Desa Wukirsari Kecamatan Cangkringan Kabupaten Sleman Yogyakarta. Skripsi. Yogyakarta .2017 